\title{
Physicality and language learning
}

\author{
Jaeuk Park ${ }^{1}$, Paul Seedhouse ${ }^{2}$, Rob Comber ${ }^{3}$, and Jieun Kiaer ${ }^{4}$
}

\begin{abstract}
The study draws on the digital technology which allows users to be able to learn both linguistic and non-linguistic skills at the same time. Activity recognition as well as wireless sensor technology, similar to a Nintendo Wii, is embedded or attached to the equipment and ingredients, allowing users to detect and evaluate progress as they carry out their cooking tasks in a real world kitchen. 48 adult participants from 20 countries in total cook, both in a digital kitchen by using real objects and in the classroom by looking at typical pictures/photos in the textbook. These learners from diverse cultural background pose a great potential to the generalizability of the current study. Research questions are: does using real objects to cook in the digital kitchen help students learn vocabulary items better than looking at photos of the objects in the classroom? If so, to what extent? This study attempts to see the effect of physicality in combination with digital technology on foreign vocabulary learning by a experimental design. This project not only helps address well-known problems in relation to classroom teaching and learning, but supports the development of innovative information and communications technology for language learning across the world.
\end{abstract}

Keywords: CALL, human-computer interaction, task-based learning and teaching, vocabulary learning, digital kitchen.

\section{Introduction}

With state-of-the-art technology evolving at an impressive rate, educators in a number of countries are keeping up with the times and waking up to globallanguage learning; a good command of English and one or more other languages are must-have skills for social and economic, and political purposes (Brecht \&

\footnotetext{
1. Newcastle University, Newcastle upon Tyne, United Kingdom; j.u.park@ncl.ac.uk

2. Newcastle University, Newcastle upon Tyne, United Kingdom; paul.seedhouse@ncl.ac.uk

3. Newcastle University, Newcastle upon Tyne, United Kingdom; robert.comber@ncl.ac.uk

4. Oxford University, Oxford, United Kingdom; jieun.kiaer@orinst.ox.ac.uk
}

How to cite this article: Park, J., Seedhouse, P., Comber, R., \& Kiaer, J. (2016). Physicality and language learning. In S. Papadima-Sophocleous, L. Bradley \& S. Thouësny (Eds), CALL communities and culture - short papers from EUROCALL 2016 (pp. 375-379). Research-publishing.net. https://doi.org/10.14705/rpnet.2016.eurocall2016.591 
Ingold, 1998). The world-languages other than English include Spanish, French, German, Chinese, Japanese and Korean, all of which have more than 50 million native speakers, according to the report by Lewis, Gary, and Charles (2016). New methods and technologies have opened up incredible opportunities of learning these popular languages, giving access to real-connection in real-world environments.

This study used the digital kitchen as a real-world digital learning environment (Seedhouse, forthcoming) because the space provides learners with a chance to carry out a real world activity: cooking (see Figure 1). The kitchen also provides a tangible connection to both what Nattinger (1988) claims as a 'situational set' of cooking items by which learners can employ physical object for learning and to what Skehan (1998) referred to as "real world activities" (p. 95) during which learners use authentic language for communicative purposes. Cooking in kitchens is an important part of daily life for many, and an activity with a clear goal, providing helpful tasks in relation to learning; Trubek and Belliveau (2009) suggest that "cooking engages students at an almost instinctive level; the smells, sounds, sights, textures and tastes excite senses and intellect" (p. 16). Considering the nature of the kitchen and its relevance to learning, it is significant to understand the impact of cooking on vocabulary learning in using kitchen environments as learning platforms.

Figure 1. The Korean digital kitchen

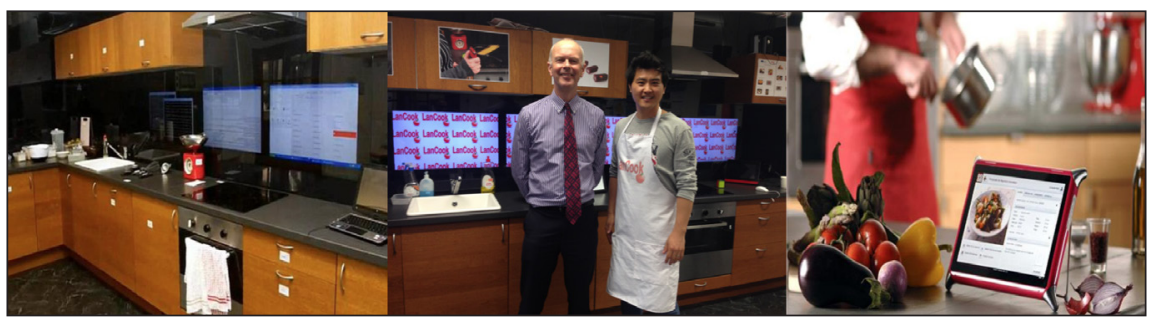

Computer technology has allowed for a wide range of learning platforms for language teaching and learning, one of which is Computer-Assisted Language Learning (CALL) in combination with Task-Based Learning and Teaching (TBLT) (Hinkelman \& Gruba, 2012; Salmon, 2011). However, most studies have used TBLT principles just to focus on tasks carried out in the classroom to develop language skills, and few studies have drawn on the real-world tasks out of the classroom, such as asking for directions in the street. Research is therefore needed in which learners carry out the real world task of cooking in a digital kitchen to see 
the difference in learning from when doing tasks in a conventional setting. This is the research gap the current study attempts to bridge, using a computer and TBLT to examine its effect on vocabulary learning.

\section{Method}

There were 48 adult participants from 20 different countries in Newcastle. A total of 24 pairs were chosen to a group. This experimental study was designed to find out which environment, a classroom or a digital kitchen is more effective than the other in promoting vocabulary gain, and which specific aspect contributes to language learning.

Six pairs (Group A) made the dish using Recipe 1 in the classroom and then Recipe 2 in the digital kitchen, while another six pairs (Group D) made Recipe 2 in the digital kitchen and then Recipe 1 in the classroom. Similarly, Group C performed the task using Recipe 2 in the classroom and Recipe 1 in the digital kitchen while Group D carried out its tasks, Recipe 2 in the digital kitchen and Recipe 1 in the classroom. It is thus possible to compare the four Groups. Two recipes have different sets of vocabularies and the same level of difficulty.

The difference between the two settings is that participants in the kitchen use real objects to cook, whereas they simply use photos of objects in the classroom. So, the kitchen users could have all five senses, while classroom learners only accessed a few senses. In the two different settings, learners went through exactly the same test and task procedures in each cooking session; the pre-test assessed ten noun vocabulary items; the exercise pre-task required users to collect each item; the during-task exercise asked them to manipulate items to cook; the post-task exercise requested evaluation; and the post-tests tested their knowledge. Given the nature of the classroom, learners did simulate cooking by interacting with a teacher using the computer, which was not sensor-based, but they were given the same feedback as in the kitchen on their request.

\section{Results}

The mean difference for four tests were higher in a digital kitchen than in a classroom and turned out to be statistically significant: immediate receptive test $M D=1.58, p<.00$, immediate productive test $M D=1.78, p<.00$, delayed receptive test $M D=0.83, p<.04$, and delayed productive test $M D=2.12, p<.00$. Furthermore, 
in the kitchen, learners used the real objects to the point where they understood the form and meaning of a target word, whereas in the classroom, simple images of the objects seemed to keep them relatively away from learning.

\section{Discussion}

The statistical analyses showed a clear distinction between the two different learning environments. Overall the digital kitchen users scored significantly higher than the classroom ones. In both settings, we could observe that learners used not only each other, but also a computer as learning resources. However, being able to manipulate physical objects in a digital kitchen plays an instrumental role in linking linguistic knowledge to their memory. Nattinger (1988) argues that physical movements help make memory connections, while in a classroom participants may simply rely on their own imagination. The way learners performed the task in the digital kitchen demonstrated more interaction in terms of negotiation, repetition, information transfer and autonomy between peers, compared to the one in the classroom. This might cause different learning outcomes.

The findings of this study suggest that being able to manipulate real objects in the digital kitchen environment can help students obtain vocabulary knowledge. In contrast, learners in the classroom simply used photos, which allowed them to use a few senses. This might keep them from internalizing the memory, thereby resulting in less successful learning. Moreover, being able to manipulate real objects using multi-senses was found to aid vocabulary learning, lending support to former studies (Nattinger, 1988; Trubek \& Belliveau, 2009). Thus, using concrete objects provided learners with more vivid and meaningful experiences. Our findings show that physicality enriches vocabulary learning. This study broadened the research scope of the vocabulary learning in TBLT and CALL by using the real world environment of a kitchen.

\section{Conclusions}

The answer to the research question is that learners were able to learn foreign vocabulary in the digital kitchen better than in the classroom, because of the different levels of physicality and interactional features in the two separate settings. Yet, the digital kitchen did not suit all learning styles. Nevertheless, the majority of learners preferred the digital kitchen to learn foreign language. Given a range of affordances such as self-organizability, motivation, and meaningful tasks 
in the digital kitchen, it is however not yet clear exactly which factor resulted in the contrasting outcome. Therefore, recommended future research would be to undertake more controlled experiments.

The findings of the present study implies not only an additional value in the literature of TBLT and CALL, but also a need for potential changes in school curricula and practices in second language teaching and learning as this technology will be able to complement the main learning activities.

\section{References}

Brecht, R. D., \& Ingold, C. W. (1998). Tapping a national resource: heritage languages in the United States. Washington, DC: Center for Applied Linguistics.

Hinkelman, D., \& Gruba, P. (2012). Power within blended language learning programs in Japan. Language Learning \& Technology, 19(2), 46-64.

Lewis, M. P, Gary, F. S., \& Charles, D. F. (Eds). (2016). Ethnologue: languages of the world (19th ed.). Dallas, Texas: Summer Institute of Linguistics.

Nattinger, J. (1988). Some current trends in vocabulary teaching. In R. Carter \& M. McCarthy (Eds), Vocabulary and language teaching (pp. 62-82). London: Longman.

Salmon, G. (2011). E-moderating: the key to online teaching and learning (3rd ed.). New York: Routledge.

Seedhouse, P. (forthcoming). Task-based language learning in an immersive digital environment: the European digital kitchen. London: Bloomsbury.

Skehan, P. (1998). A cognitive approach to language learning. Oxford: Oxford University Press.

Trubek, A. B., \& Belliveau, C. (2009). Cooking as pedagogy: engaging the senses through experiential learning. Anthropology News, 50(4), 16-16. https://doi.org/10.1111/j.15563502.2009.50416.x 


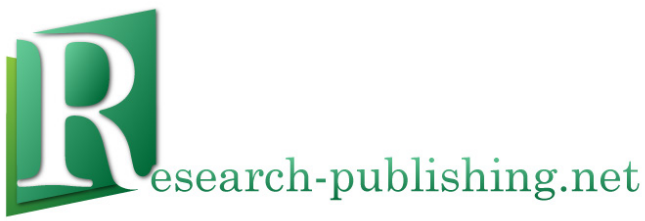

Published by Research-publishing.net, not-for-profit association Dublin, Ireland; Voillans, France, info@research-publishing.net

(C) 2016 by Editors (collective work)

(C) 2016 by Authors (individual work)

\section{CALL communities and culture - short papers from EUROCALL 2016 Edited by Salomi Papadima-Sophocleous, Linda Bradley, and Sylvie Thouësny}

Rights: All articles in this collection are published under the Attribution-NonCommercial -NoDerivatives 4.0 International (CC BY-NC-ND 4.0) licence. Under this licence, the contents are freely available online as PDF files (https://doi. org/10.14705/rpnet.2016.EUROCALL2016.9781908416445) for anybody to read, download, copy, and redistribute provided that the author(s), editorial team, and publisher are properly cited. Commercial use and derivative works are, however, not permitted.

\section{(9) $\Theta \Theta$}

Disclaimer: Research-publishing.net does not take any responsibility for the content of the pages written by the authors of this book. The authors have recognised that the work described was not published before, or that it is not under consideration for publication elsewhere. While the information in this book are believed to be true and accurate on the date of its going to press, neither the editorial team, nor the publisher can accept any legal responsibility for any errors or omissions that may be made. The publisher makes no warranty, expressed or implied, with respect to the material contained herein. While Research-publishing.net is committed to publishing works of integrity, the words are the authors' alone.

Trademark notice: product or corporate names may be trademarks or registered trademarks, and are used only for identification and explanation without intent to infringe.

Copyrighted material: every effort has been made by the editorial team to trace copyright holders and to obtain their permission for the use of copyrighted material in this book. In the event of errors or omissions, please notify the publisher of any corrections that will need to be incorporated in future editions of this book.

Typeset by Research-publishing.net

Cover design by (C) Easy Conferences, info@easyconferences.eu,www.easyconferences.eu

Cover layout by (c) Raphaël Savina (raphael@savina.net)

Photo "bridge" on cover by (C) Andriy Markov/Shutterstock

Photo "frog" on cover by (C) Fany Savina (fany.savina@gmail.com)

Fonts used are licensed under a SIL Open Font License

ISBN13: 978-1-908416-43-8 (Paperback - Print on demand, black and white)

Print on demand technology is a high-quality, innovative and ecological printing method; with which the book is never 'out of stock' or 'out of print'.

ISBN13: 978-1-908416-44-5 (Ebook, PDF, colour)

ISBN13: 978-1-908416-45-2 (Ebook, EPUB, colour)

Legal deposit, Ireland: The National Library of Ireland, The Library of Trinity College, The Library of the University of Limerick, The Library of Dublin City University, The Library of NUI Cork, The Library of NUI Maynooth, The Library of University College Dublin, The Library of NUI Galway.

Legal deposit, United Kingdom: The British Library.

British Library Cataloguing-in-Publication Data.

A cataloguing record for this book is available from the British Library.

Legal deposit, France: Bibliothèque Nationale de France - Dépôt légal: décembre 2016. 